\title{
Noken: Women Empowerment \& Tourism Industry in Papua
}

\author{
Machya Astuti Dewi \\ UPN "Veteran"Yogyakarta, Indonesia \\ machya@upnyk.ac.id \\ Iva Rachmawati \\ UPN "Veteran"Yogyakarta, Indonesia \\ iva.rachma@gmail.com
}

\author{
Meilan Sugiarto \\ UPN "Veteran"Yogyakarta, Indonesia \\ msugiarto89@gmail.com \\ Sri Issundari \\ UPN "Veteran" Yogyakarta, Indonesia \\ issundari.ari@gmail.com
}

\begin{abstract}
This article aims to explain the opportunities of wicker bags noken, as a way for Papuan women to be more empowered. Noken is a traditional handmade Papuan handbag. Currently, young women are starting to leave the tradition of weaving noken because it is considered a symbol of backwardness. Woven bag noken may improve the welfare of women as well as sustaining Papua tourism. If it is packed in an attractive way, noken can be used as a souvenir icon of Papua. In turn, it develops the tourism industry and a means of women empowerment. This article describes the opportunities for women's empowerment in supporting the tourism industry through the development of woven bags noken. The research took place in Merauke district of West Papua.
\end{abstract}

Keywords: noken, poverty, women empowerment, tourism industry

\section{INTRODUCTION}

The Local Government of Merauke is creating many efforts to develop local tourism. The development of Merauke tourism refers to the Law of the Republic of Indonesia Number 10 Year 2009 and the Policy of the Regional Government of Merauke Regency which aims to create a better social life that covers the political, economic, social and cultural aspects, security and order. The program is embodied in the vision of development of Merauke Regency Government Year 2011-2016 that says "Merauke Gerbang Andalan Manusia Cerdas dan Sehat, Gerbang Pangan Nasional, Gerbang Kesejahteraan dan Kedamaian Hati Nusantara (Merauke the Gate of Intelligent and Healthy People, National Food Gate, Welfare Gate and Peace of the Nusantara Heart)[1].

Noken is a typical Papuan wicker bag that has the potential to support Merauke tourism development. Noken plays as a classicand real local tourism souvenir. As one of Papuan culture symbols passed down from generation to generation, noken is woven by women from middle aged ("mama-mama") to young girls ${ }^{1}$. Noken represent the closeness between Papuan women since they make and wear it.
The existence of noken is currently worrying as fewer Merauke women are interested in making and marketing it. An article written by Kornelis Kewa Ama mentions that people in Papua often assume that noken (and other local wisdom products such as saly, koteka, arrow bow, tubers, and some other uniqueness of Papua) is a symbol of "backwardness" [2]. Noken has not been considered a valued item as it is considered out of date. Many young Papuan women leave noken and replace them with modern bags made of leather or plastic. It is not surprising that noken is an unattractive item and it is more common to be displayed in street vendors than in major stores [3]. A noken craftswoman, Mama Lien (35 years old) from Nabire does not have permanent place to sell noken, so that she sells it at the port when passenger ships come in. Like Mama Lien, many noken craftswomen in Jayapura sell it in the grocery store, supermarket, or sidewalk.

This article aims to illustrate the potential of noken which, if managed properly, can be used as a means to support Merauke tourism by empowering women as craft workers. Noken may develop women empowerment and independency. Noken also helps to decrease poverty which cover Merauke times to times.

\section{THE CONDITION OF PAPUAN WOMEN AND THE DEVELOPMENT OF TOURISM INDUSTRY}

Papua is the most-eastern province in Indonesia. Compared to other provinces in Indonesia, Papua seems to be left behind in terms of infrastructure, human resources and technological development, despite the fact that the province is wealthy of natural resources and abundant culture.The facts show that Papua Province has a relatively high poor population compared to other provinces, ranking the first place of 28.40 percent (see Table 1)

High poverty rates in this area indicate that there are gaps related to governance and community services, fund management, human resource quality improvement, limited availability of infrastructure, and breadth of service areas with uneven distribution of populations in isolated and border areas of RI-PNG . 
Table 1 . The poverty rate in Indonesia in 2016

\begin{tabular}{llcc}
\hline No & \multicolumn{1}{c}{ Provinsi } & $\begin{array}{c}\text { Jumlah } \\
\text { Penduduk Miskin } \\
\text { (ooo orang) }\end{array}$ & $\begin{array}{c}\text { Persentase } \\
\text { Penduduk Miskin } \\
(\%)\end{array}$ \\
\hline 1 & Papua & 898,21 & 28,40 \\
2 & Papua Barat & 225,54 & 25,73 \\
3 & Nusa Tenggara Timur & 1160,53 & 22,58 \\
4 & Maluku & 327,77 & 19,36 \\
5 & Gorontalo & 206,52 & 18,16 \\
6 & Bengkulu & 322,83 & 17,16 \\
7 & Aceh & 859,41 & 17,11 \\
8 & Nusa Tenggara Barat & 802,29 & 16,54 \\
9 & Sulawesi Tengah & 406,34 & 14,07 \\
10 & Sumatera Selatan & 1112,53 & 13,77 \\
\hline
\end{tabular}

Source: Ministry of Women's and Children's Empowerment of Republic of Indonesia Studies of Provincial and District Policy on Poverty Reduction through Home Industry; Study in Jayapura District, Papua, Jakarta, 2016

Women become one of the victims in the poverty problems. One source of discrimination and subordination to women originates from the household. Women tend to be in sub ordinance, makes them in weak position because of the patriarchal culture. In terms of domestic matter, there is an inequality in resource allocation, which cause women often suffer from the restriction on employment [5]. Meanwhile, according to Hubeis and Mulyandari, poor women suffer more than poor men and suffer more than fellow women who come from a better economic class. There are some common conditions for poor people: lack of food, low income, untreated diseases due to cost and access to health facilities, poor nutrition, unhealthy homes, poor environment and poor water supply [2].

Women in Merauke district become one of the victims of the problem of poverty, inequality and injustice. The fundamental problem in Merauke (Papua) begins with the traditional Papuan women's position and duties in the family home. New issues of Papuan women began to rise as they entered their "new world" of married life. In their "new world", they might be confronted with other problems, for instance, husband violence (usually it is related to dowry paying to the wife's parents). The culture may play a role to put women in second-class citizens. The general picture of women in Merauke seems to describe their pressure from many sides. The pressure can come from family, community or culture. In such situations women need to increase their participation and prosperity.

One of the efforts to improve women's welfare is empowerment. Women empowerment basically puts women as the driving force of the economy. Empowerment is expected to provide opportunities for women to free themselves of the poverty problems. In addition, tourism may offer a solution to involve women. Also, tourism has the opportunity to increase local revenues.

Merauke district has the potency to be developed into a tourist area through the development of creative economy. Papua has a wealth of culture, handicrafts and exceptional local wisdom. The existing handicrafts in Papua are in line with the three sectors of the creative economy developed by the government [6]. In this case, local wisdom believed can be beneficial to support the development of the creative economy. For example, people of Merauke can create iconic and typical souvenir for tourism project. Noken is a form of local wisdom that can be transformed into afascinating item that might become the icon of Merauke tourism.

\section{NOKEN AS A MEANS TO SUPPORT THE TOURISM INDUSTRY AND EMPOWERMENT}

Noken has a long philosophy that symbolizes the form of local wisdom of native Papuans. Noken is a term commonly used in Papua to mention a traditional women's bag in Papua. The word noken itself comes from Biak accent, namely inokson or inoken. However, each tribe in Papua has a different name for noken. For example people in Biak Numfor call nokeninokson. The Dani people in the Baliem Valley call it su. People living in Harlens call noken in Moorish aramuto, in SentaniJayapura district, noken is called holoboi, and Marind people in Merauke district call nokenmahyan [5]

Noken has an important role either functionally, philosophically or culturally. Functionally nokenis a typical Papuan traditional bag that is used to carry anything. Large noken are usually used to carry items such as firewood, crops in the garden, groceries, used in traditional ceremonies, or even used to carry a child. The small noken are used to carry personal items [2]. Philosophically noken means fertility. Papuans in the past believed that a woman who did not know how to make noken was considered immature. If a women was able to weave noken, she was considered an independent adult, who was capable of working and deserved to get married. Accordingly, noken now becomes symbol of fertility and peace for the people of Papua ${ }^{2}$. Culturally, the noken bags are given to sign welcome and goodbye or as a gift of a memento [7]. Noken is given as a welcome gift for family members or relatives who live far away [8].

Noken has a variety of basic materials ranging from whole-stitched wood bark, stitched nibun bark, knitted bark knife to woven pandanus leaf-shaped bag. According to Paul Yam, in ancient times women used coconut leaves and matting leaf woven in to a noken. Nevertheless, certain areas use sago tree branches to make noken with kamboki. Then, the materials are replaced with bark fibers [9]. Some other types of nokenare made by knitting. Noken is made of special wooden ropes that are not easily broken, such as rattan or other trees.

The existence of noken as a form of local wisdom can be utilized in order to attract tourists to shop. Shopping is generally a dominant factor when tourists travel to visit tourist places of interest [10]. According to Turner and Reisinger, tourists spend $2 / 3$ of the overall cost of travel on domestic travel, as well as $1 / 5$ of the overall cost of shopping when traveling abroad [10]. Souvenir is one of items to shop while traveling.

Surely, souvenirs produced by the local people can increase people's income. Consideringthe developing tourism industry in Merauke, noken can be improved into Merauke's classic souvenirs. Apart from it, noken can 
also provide opportunities for Merauke women to be more empowered.

Empowering women through noken will encourage them to be equal partners of men. Beti, a noken craftswoman from Sota-border of Merauke and Papua New Guinea, said that from selling noken she can help her husband fulfill their household needs. Moreover, their family income increase too ${ }^{14}$. Similarly, Albertina said that money from the noken sale is usually invested back on business to make it grows bigger [11]. Marta, another noken seller, who owns a kiosk in Sotaexplained that from noken, she can send one of her four children to Musamus University of Merauke [3]. Those examples, what Merauke women get from the noken craft makes them more empowered. This is in line with what Kabeer argued in Anju Malhotra that women's empowerment deals with women's ability to make a more strategic life choices that they previously did not have [12].

In addition to making women more empowered and independent, nokenalso encourages the tourism industry of Merauke to grow better. The presence of noken in the tourism industry will provide economic benefits for the community. The tourism industry plays a major role in fostering economic and social development [3]. This sector stimulates economic growth by generating revenue, employment, investment and exports. In addition, tourism also develop new jobs in remote areas. Previously, those areas were not considered as profitable for government and society. Martha, a noken seller on the border of Merauke-Papua New Guinea, said that every time a noken is finished, it can be sold directly to the tourists who visited the border. In two weeks she can sell seven pieces of noken with various prices and sizes ${ }^{3}$. Similarly, Albertina said that in one week she usually sells five to seven handmade noken [12]. The profit from noken really helps the women to fulfill their needs.

\section{CONCLUSION}

The tourism industry is growing along with the increasing mobility of citizens from one region to another. The factors supporting the tourism industry is increasingly important in line with the spirit of the region to compete and make the region the main tourist destination. Souvenirs become main product that represents typical identity of a regional tourism.
Through noken, Merauke tourism industry becomes very potential to be developed while providing opportunities for Merauke women to be more empowered. Noken puts women as the creator as well as users. The empowerment of Merauke women through noken can help them release the restraints of ignorance, poverty and backwardness that cover Merauke for a long time.

\section{ACKNOWLEDGMENT}

The author would like to thank to the: Ministry of Research and Technology of Higher Education for Providing research funding Hibah Strategis Nasional 2018 which allows the implementation of this research. Hopefully this research will be useful for the development of tourism industry in Indonesia.

\section{REFERENCES}

[1] "Noken Asal Biak Terancam Punah", 23 Oktober 2012fromhttp://nasional.kompas.com/read/2012/10/ 23/16413811/Noken.Asal.Biak.Terancam. Punah access on 25 January 2018.

[2] "Kearifan Lokal Papua yang Lama Terabaikan" from http://www.wacana.co/2009/03/kearifan-lokalpapua-yang-terabaikan/access on 25 January 2018.

[3] V. S. Hubeisdan R. S. H. Mulyandari, "Analisis Teori Performance dan Positioning: Komunikasi Pembangunan Berwawasan Gender" from Jurnal Komunikasi Pembangunan, ISSN 1693-3699 Februari 2010, Vol. 08, No. 1

[4] Siti Farit Hardiana, "Mengenal Noken-Papua, Tas Rajutan Khas Papua" darihttps: //www.vebma.com/unik/ NokenPapua/944aksestanggal 9 Maret 2018

[5] Mrs. Martha, personal interview on 26 April 2018

[6] A. Athanasopoulou, Tourism as A Driver of Economic Growth and Development in the EU-27 and ASEAN Regions, EU Centre in Singapore, Singapore, 2013.

[7] Mrs. Martha, personal interview on 26 April 2018. 